\title{
Relevansiacara Adat Akken Waghei (Angkat Keluarga) dalam Mewujudkan Harmoni dan Kebhinekaan di Kebandaran Mergo Sekampung Udik di Kabupaten Lampung Timur
}

\author{
Sainul dan Fredy Gandhi Media \\ Institut Agama Islam Negeri (IAIN) Metro \\ E-mail: kanjengsainul10@gmail.com
}

\begin{abstract}
A culture that lead to sanctions are called as customary law. It occurs to bind existing parties within the scope of mores. It treatiesto build the public laws. The treaty made must be kept in the covenant of Islam. Misbehavior is the king's official statement of the recognition of the territorial autonomy of the kingdom that governed himself. Kebangaran Mergo Sekampung Udik is an autonomous region of the Banten government under the sultanate of Maulana Hasanudin. Maulana Hasanudin reigned over Pugung's unity in Lampung, after subduing Pugung's Keratuan through Marriage. In the indigenous communities of Lampung Mergo Sekampung Udik recognize an Akken Waghei, customs that allow the adoption of family and carried out by adopting an Islamic pledge. It is a solution to maintain good relationships, eradicate family problems, resolve disputes peacefully. It held by a party, even between tribes. Akken waghei is important in order to realize harmony in difference
\end{abstract}

Key Word: Akken Waghei, Bandar, Mores, Customary Law, Pledge, Harmony

\begin{abstract}
Abstrak
Sebuah budaya yang menyebabkan sanksi disebut sebagai hukum adat. Hal ini terjadi untuk mengikat pihak yang ada dalam lingkup adat istiadat. Ini treatiesto membangun hukum publik. Perjanjian yang dibuat harus disimpan dalam perjanjian Islam. Kenakalan adalah pernyataan resmi raja dari pengakuan otonomi wilayah kerajaan yang diperintah sendiri. Kebangaran
\end{abstract}


Mergo Sekampung Udik adalah daerah otonomi dari pemerintah Banten di bawah kesultanan Maulana Hasanudin. Maulana Hasanudin memerintah atas kesatuan Pugung di Lampung, setelah menundukkan Pugung ini keratuan melalui Pernikahan. Dalam masyarakat adat Lampung Mergo Sekampung Udik mengakui Akken Waghei, adat istiadat yang memungkinkan adopsi keluarga dan dilakukan dengan mengadopsi janji Islam. Ini adalah solusi untuk menjaga hubungan baik, memberantas masalah keluarga, menyelesaikan sengketa secara damai. Hal yang diselenggarakan oleh salah satu pihak, bahkan antara suku-suku. Akken waghei penting dalam rangka mewujudkan kerukunan dalam perbedaan

Kata Kunci: Akken Waghei, Bandar, Adat Istiadat, Hukum Adat, Janji, Harmoni.

\section{A. Pendahuluan}

\section{Latar Belakang Masalah}

Hukum adat adalah aturan kebiasaan manusia dalam hidup bermasyarakat. ${ }^{1}$ Untuk menjamin pelaksanaan adat atau hukum adat tersebut dalam masyarakat maka kesepakatan masyarakat menunjuk sekelompok kecil orang untuk mengatur, menyelenggarakannya, yang disebut dengan Tokoh Adat. ${ }^{2}$ Hukum adat pada hakekatnya merupakan hukum kebiasaan, artinya kebiasaan-kebiasaan yang mempunyai akibat hukum, yang timbul dari perbuatan yang diulang-ulang dan selanjutnya hal tersebut dirasakan tidak lazim, maka dapat diberikan sanksi. Dalam seminar hukum adat dan pembangunan hukum nasional, dijelaskan bahwa hukum adat adalah hukum asli yang tidak tertulis dalam bentuk perundang-undangan republik Indonesia yang

\footnotetext{
${ }^{1}$ Hilman Hadikusuma, Pengantar Ilmu Hukum Adat Indonesia, (Bandung, Mandar Maju, 2003), hlm. 1

${ }^{2}$ Ibid, hlm. 2-3.
} 
mengandung unsur agama. ${ }^{3}$ Hukum adat berbeda dengan adat, karena adat adalah sebatas kebiasaan, sedangkan hukum adat ditandai adanya sanksi atas penyimpangan yang timbul dan pelaksanaannya terpusat pada lembaga tertentu dimasyarakat. ${ }^{4}$

Keluarga merupakan persekutuan terkecil dalam masyarakat, lahirnya keluarga dikarenakan adanyahubungan perkawinanhubungan Semenda, danproses adopsi.Sedangkan hubungan keluarga yang timbul karena hal lain, pada masyarakat lampung dapat dilihat pada; akibat perwalian, angkat anak (akken anak), masuk dalam kekerabatan kerabat lain atau dimasukkan dalam adat (Lampung) dari salah satu tokoh adat tertentu (kughuk adat), dan angkat keluarga didasarkan pada sumpah (akkat waghei suppah). Cara-cara ini merupakan sebab timbulnya kekeluargaan pada sistem kekerabatan orang lampung, disamping cara yang umum yaitu dengan cara perkawinan.

Budaya angkat keluarga (akken waghei) adalah budaya mengangkat kerabat/keluarga dengan pengambilan sumpah yang telah menjadi kebiasaan dari nenek moyang orang lampung. Sebuah tradisi yang dipandang perluuntukdilestarikan guna menjamin hubungan harmonis antara satu individu dengan individu lainnya. Tradisi ini dilakukan dengan beberapa alasan atau latar belakang.Pertama: dilakukan untuk menjamin hubungan yang telah terjalin agar terus baik dan terhindar dari perselisihan, Kedua: untuk memberikan solusi atas ketidak sempurnaan keluarga demi mewujudkan keluarga yang lengkap terdiri dari ayah, ibu dan anak, di sini membuka

${ }^{3}$ C. Dewi Wulandari, 2010, Hukum Adat Indonesia Suatu Pengantar, PT. Refika Aditama, Bandung, hlm. 6

4. Soekanto dan Soerjono soekanto, Pokok-Pokok Hukum Adat, (Alumni, Bandung1978), hlm. 17

Fikri, Vol. 3, No. 1, Juni 2018 
peluang angkat anak/adopsi, Ketiga: sebagai manifestasi dan perwujudan sikap manusiawi bagi individu yang patut dilindungi dan dibantu, yang Keempat: untuk menyelesaikan masalah jika terjadi perselisihan, sehingga dengan acara akken wagheiini akan terhapus dendam dan hubungan akan baik kembali, bahkan lebih baik dari sebelumnya, karena sudah diangkat keluarga (sebagai orang tua, sebagai saudara, sebagai anak).

Akkenwagheibisa dilakukan tidak hanya pada masyarakat adat Lampung pribumi atau orang Lampung (Jimo Lappung), tetapi berlaku lintas suku. Pribumi asli Lampung dan Lampung pendatang dari suku lain hidup bermasyarakat secara rukun, damai, dan harmoni dalam kebhinnekaan dengan slogan Sang Bumi Ruwa Jurai.

Adatakken waghei sering dipraktikkan oleh masyarakat adat Lampung, khususnya di masyarakat adat Lampung kebandaran Mergo Sekampung Udik Lampung Timur, dan praktikakken waghei ini setiap tahun dipastikan terjadi, dengan perkiraan 360 praktik akken waghei tiap tahunnya. ${ }^{5}$ Hal ini menunjukkan bahwa pengakuan kekerabatan melalui praktik adat akken wagheimerupakanpraktik peradatan untuk mengatasi kesenjangan sosial, dan hal itutentu memiliki dampak hukum bagi masyarakat, karena di dalam prosesi akkenwaghei terdapat sumpah dan janji-janji oleh mereka yang melakukan akkenwaghei.

\section{Rumusan Masalah}

Berdasarkan uraian pada latar belakang masalah diatas, maka penulis mengangkat beberapa pertanyaan penelitian, yaitu:

\footnotetext{
${ }^{5}$ Wawancara dengan P3N, Hasan (Toba), Yunus (Bojong), Yusup (Gn,
} Sugih), Yakup (Gunung Raya, Sulaiman (Paniangan), Idris (Batubatada) tanggal 2 Juli 2017. 
a. Bagaimana praktik sumpah sebagai dasar akken waghei (angkat keluarga) dalam adat Bandar Mergo Sekampung (Udik) Lampung Timur dalam persfektif Islam?

b. Apa dampak akken waghei (angkat keluarga) terhadap harmoni dalam kebehinnekaan masyarakat adat Bandar Mergo Sekampung Udik Lampung Timur?

\section{Metodologi Penelitian}

Penelitian ini menggunakan metode penelitian kualitatif etnografi. Dalam penelitian ini peneliti menggunakan teknik pengumpulan data yang pertama adalah observasi, yang mana digunakan untuk menggali data dari sumber data yang berupa peristiwa, tempat atau lokasi dan benda serta rekaman gambar. ${ }^{6}$ Dalam penelitian ini peneliti menggunakan teknik observasi langsung dengan mendatangi peristiwanya. Yang kedua menggunakan wawancara yang dilakukan dengan cara mengadakan komunikasi langsung dengan pihak-pihak yang dapat mendukung diperolehnya data yang berkaitan dengan permasalahan yang diteliti guna memperoleh data baik lisan ataupun tulis atas sejumlah data yang diperlukan. ${ }^{7}$

Untuk menganalisis data, penulis menggunakan content analysis (analisis isi), sebagaimana Burhan Bungin yang dikutip oleh Cahyono menyatakan bahwa content analysis adalah suatu metodologi penelitian yang memanfaatkan seperangkat prosedur untuk menarik kesimpulan yang sahih dari sebuah buku atau dokumen. ${ }^{8}$

${ }^{6}$ Syarwani Ahmad dkk., "Desain Pembelajaran SMA Plus Negeri 2 Banyuasin III Berbasis Karakter Di Era Masyarakat Ekonomi ASEAN," Iqra': Jurnal Kajian Ilmu Pendidikan 2, no. 2 (2017): 410.

${ }^{7}$ Ahmad dkk., 410.

${ }^{8}$ Heri Cahyono, Suhono Suhono, dan Aisyah Khumairo, "Pendidikan Karakter Bagi Pelaku Pedofilia (Sebuah Strategi Dalam Mengatasi Amoral)," 


\section{B. Adat, Hukum Adat}

Kebiasaan yang berkaitan dengan masyarakat disebut adat dan adat yang diberikan kekuatan mengikat disertai sanksi disebut Hukum Adat. Istilah Hukum adat untuk membedakan hukum yang berlaku yang ada pada praktek bernegara dimana hukum ada yang tertulis, yaitu perundang-undangan dengan hukum yang berasal dari masyarakat yang tidak tertulis disebut hukum adat. ${ }^{9}$ Kebiasaan pribadi disebut adat. Adat yang mengikat disertai sanksi disebut hukum Adat. Hukum adat Indonesia memiliki corak tradisional, keagaamaan, kebersamaan, konkret dan visual, terbuka dan sederhana, dapat berubah dan menyesuaikan, tidak dikodefikasi, musyawarah dan mufakat. ${ }^{10}$ Hukum adat digali dari nilai budaya asli daerah budaya setempat, yang sangat kental dengan ajaran agama (Islam), dibangun dari oleh untuk masyarakat itu sendiri demi kepentingn bersama, hukum adat bersifat tunai dan diwujudkan dari perilaku budaya setempat, didasarkan hasil musyawarah dan permufakatan.

Masyarakat hukum adat adalah masyarakat yang hidup secara berkelompok, dimana menundukkan diri pada kebiasaan adat dalam masyarakatnya, secara normatif perilaku ini disadari bahwa hal tersebut seharusnya demikian secara kolektif (conditio since quanon). Untuk menjamin pelaksanaan tertib masyarakat maka sebagian kecil dari masyarakat diberikan otoritas menyelenggarakan penegakan etika atau norma yang ada, hal ini bagi yang diberikan otoritas selanjutnya disebut tokoh adat, otoritas diberikan berdasarkan perjanjian atau kontrak sosial (Social Contract).

JMKSP (Jurnal Manajemen, Kepemimpinan, dan Supervisi Pendidikan) 3, no. 1 (2017).

${ }^{9}$ Hilman Hadikusuma, Pengantar Ilmu Hukum Adat Indonesia, (Bandung, Mandar Maju, 2003), hlm.2

${ }^{10}$ Ibid, hlm. 33 
Persekutuan hukum adat, dapat dikelompokkan menjadi; Pertama: masyarakat hukum territorial (masyarakat terikat berdasarkan daerah kediaman) tertentu. Kedua: Masyarakat hukum Geneologis (anggota masyarakat terikat berdasarkan garis keturunan yang sama), dibedakan atas Patrilinial (susunan masyarakatnya ditarik dari keturunan garis bapak (garis lakilaki) dan Matrilinial (susunan masyarakatnya ditarik dari keturunan garis ibu (garis wanita) serta billateral (susunan masyarakat campuran berdasarkan garis keturunan bapak dan ibu), ketiga: masyarakat hukum territorial-geneologis, (masyarakat hukum terikat pada tempat kediaman dan sekaligus juga terikat pada keturunan), dimana garis keturunan mengikat walau domisili tidak dalam territorial, misal Marga Batak, Kebuwaian di Lampung. Keempat: Masyarakat adat-keagamaan. Masyarakat hukum yang berdomisili didasarkan kelompok agama yang dianut, sedang di Lampung ada perkampungan (tiyuh) atau pekon bagi peribumi kampung, dan desa bagi orang pendatang secara umum. Di Lampung Timur ada desa yang domisili penduduknya didasarkan agama, seperti Hindu berasal dari suku Bali seperti di Negeri Jemantan, Gedong Wani, Sukaraja Tiga, Jayaguna. Kelima: masyarakat adat di perantauan, hal ini digambarkan pada pembentukan kerukunan seperti kerukunan kematian dan masyarakat adat lainnya, seperti organisasi masyarakat, LSM. ${ }^{11}$

\section{Ketentuan Sumpah}

Sumpah diartikan, pertama: Pernyataan yang diucapkan secara resmi dengan bersaksi kepada Tuhan atau kepada sesuatu yang dianggap suci (untuk menguatkan kebenaran dan kesungguhan dan sebagainya: (perkataannya itu dikuatkan dengan), kedua: Pernyataan disertai tekat melakukan sesuatu

\footnotetext{
${ }^{11}$ Ibid, hlm.108-114
}

Fikri, Vol. 3, No. 1, Juni 2018 
untuk menguatkan kebenarannya atau berani menderita sesuatu kalau pernyataan itu tidak benar, ketiga: Janji atau ikrar yang teguh (akan menunaikan sesuatu). Ucapan sumpah dan media sumpah secara umum dilakukan berbeda-beda, hal ini dikarenakan pengaruh dari daerah, kesukuan dan agama yang berbeda-beda.

Berkaitan dengan ketentuan sumpah yang digambarkan dapat difahami bahwa sumpah dilakukan oleh seseorang, adanya perkataan atau pernyataan dengan sungguh-sungguh sebagai ikrar atau janji, didasarkan pada sesuatu berupa ancaman sanksi $(a d z a b)$ berdasarkan keyakinan.

1. Sumpah Dalam Adat

Interaksi antara masyarakat adat menimbulkan perbuatan hukum, perbuatan hukum dibedakan perbuatan hukum yaitu perbuatan yang sesuai hukum dan perbuatan hukum yang melanggar hukum. Perbuatan hukum dalam masyarakat yang melanggar hukum adat disebut delik adat (adatdelicten recht). Delik adat bersifat tradisional magis religius, menyeluruh dan menyatukan, tidak menyamaratakan, terbuka dan lentur, melanggar ketentuan adat, misal Kuntara Raja Niti, hukum adat masyarakat Lampung, delik aduan, pertanggungjawaban kesalahan, tempat berlakunya. ${ }^{12}$ Delik adat dapat digambarkan sebagai berikut: kesalahan karena mengganggu keamanan, ketertiban, kesopanan dan kesusilaan, melanggar perjanjian, menyangkut tanah-tanam tumbuhaan-hasil hutan, menyangkut hewan ternak dan perikanan. ${ }^{13}$

Dalam pengangkatan sumpah dihadiri para tokoh masyakat dan tokoh adat dimaksudkan penyelesaian perkara delik secana perdamaian. Penyelesaian ini secara hukum

\section{1-238}

${ }_{12}$ Hilman Hadikusuma, Pengantar Ilmu Hukum Adat Indonesia, hlm.

${ }_{13}$ Ibid, hlm 238-239.

Fikri, Vol. 3, No. 1, Juni 2018 
dibenarkan oleh hukum adat setempat, bahkan dibenarkan dalam hukum negara, diatur dalam pasal 3a RO tentang "Peradilandesa.". ${ }^{14}$ Sumpah dalam masyarakat adat memiliki peran penting untuk menjamin hubungan masyarakat hukum adat, agar tidak terjadi delik. Sumpah dalam delik adat bertujuan pertama, untuk memelihara hubungan baik agar tidak terjadi delik adat. kedua, untuk menyelesaikan masalah karena delik adat. Sumpah timbul karena adanya ucapan yang diucapkan dengan sungguh-sungguh berisi perjanjian atas nama tuhan dan atau lainnya untuk menguatkan, meyakinkan.

Perjanjian secara hukum mempunyai kekuatan mengikat, perjanjian yang dibuat bila dilanggar dikenakan sanksi, dimana perjanjian berlaku sebagai undang-undang. Perjanjian merupakan ikrar dilakukan dalam sumpah maka sumpah menimbulkan ketakutan akan kekuatan tuhan berupa adzab, kutukan dan dosa.

2. Sumpah Dalam Islam

Sumpah dalam bahasa Arab ialah al-aiman (الأيمان) yang merupakan jamak dari perkataan al-Yamin (اليمين). Pada dasarnya sumpah berarti tangan kerana untuk bersumpah, masyarakat Arab lazimnya mengangkat tangan kanan mereka. ${ }^{15}$ Juga, apabila mereka saling bersumpah, masingmasing memukul tangan kanannya dengan tangan kanan orang yang bersumpah. ${ }^{16}$ Adapun dari sudut istilah, ia berarti

${ }^{14}$ Peradilan desa di Lampung dilakukan di Nowo Sesat, oleh para hakim terdiri dari tokoh adat (Penyimbang) dan proses persidangan disebut sidang perwatin.

15، Abd Allah bin 'Abd al-Rahman al-Bassam - Taudhih al-Ahkam min Bulugh al-Maram (Maktabah al-Asri, Mekah, 2003)

${ }^{16}$ Abu Malik Kamal bin al-Sayyid Salim - Shahih Fiqh al-Sunnah wa Adillatuh wa Taudhih Mazahib al-Aimmah (Maktabah al-Taufiqiyyah, Kaherah, tt) 
menguatkan perkara yang disumpah dengan mengemukakan sesuatu yang agung secara khusus. ${ }^{17}$

Sumpah perlu persyaratan, Berikut diperincikan syarat ini:

a. Bersumpah atas nama Allah, Rasulullah shallallahu 'alaihi wasallam bersabda:

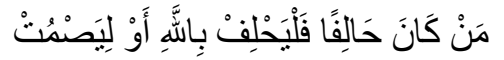

Sesiapa yang ingin bersumpah, maka bersumpahlah atas nama Allah atau (jika tidak) maka diamlah. ${ }^{18}$

Dalam praktek bagi yang akan bersumpah maka hendaklah menyebut "Wallahi", "Billahi" atau "Tallahi" yang semuanya bermaksud "Demi Allah".

b. Sumpah dengan salah satu dari nama-nama Allah.

Berdasarkan hadis di atas juga, boleh bersumpah dengan salah satu nama Allah seperti alRahman, al-Rahim, al-Khalik dan sebagainya. Seumpama: "Demi al-Rahman, aku tidak pernah melakukan hal itu". 19

c. Sumpah dengan salah satu sifat Allah.

Hadis berikut menjadi rujukan bahwa sumpah wajib disandarkan pada Allah, nama-nama Allah atau sifat-sifat Allah:

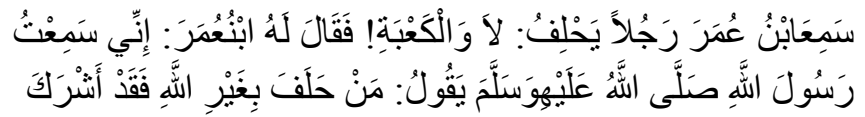

Ibn 'Umar (radhiallahu 'anhuma) mendengar seorang lelaki bersumpah: "Tidak, demi Ka'bah!" Lalu Ibn 'Umar berkata kepadanya: "Aku mendengar Rasulullah shallallahu 'alaihi wasallam

${ }^{17}$ Taudhih al-Ahkam min Bulugh al-Maram

${ }^{18}$.Sahih: Dikeluarkan oleh al-Bukhari dalam Shahihnya, hadis no: 2679 (Kitab al-Syahadat, Bab bagaimana cara bersumpah).

${ }^{19}$ Sahih Fiqh al-Sunnah 
bersabda: "Sesiapa yang bersumpah dengan selain Allah, maka dia telah berbuat syirik." 20

Sumpah yang diucapkan dengan selain Allah bukan sahaja tidak sah dan syirik, orang yang melakukannya perlu segera mengucapkan syahadah kembali, mempersaksikan bahwa "Tiada Tuhan Melainkan Allah":

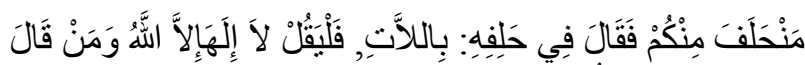

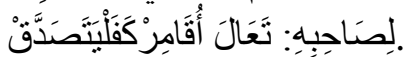

Sesiapa di antara kalian bersumpah lalu berkata dalam sumpahnya itu: "Demi Latta!", maka hendaklah dia mengucapkan La ilaha illallah. Dan sesiapa yang berkata kepada temannya: "Ayuh, aku ingin bertaruh dengan kamu", maka hendaklah dia bersedekah. ${ }^{21}$

Menurut 'Abd Allah al-Bassam Hafizhahullah, al-Yamin ialah sumpah dengan katakata khusus bagi menguatkan sesuatu yang disumpah, yaitu dengan mengemukakan sesuatu yang agung secara khusus. Orang yang bersumpah apabila ingin menguatkan sesuatu, baik dalam rangka menafikan atau menetapkan, yang disandarkan kepada yang mulia, yakni Allah SWT. Sumpah dapat memberikan manfaat atau mudarat berdasarkan sebab-sebab rasional dan tidak rasional. Apabila orang yang bersumpah menepati apa yang dia sumpahkan, maka (diyakini) yang dijadikan sandaran sumpah tersebut telah rela dan mengabulkan sumpahnya. Apabila (yang dijadikan sandaran sumpah) tidak rela, maka ia akan menimpakan

20. Sahih: Dikeluarkan oleh Abu Daud dan dinilai sahih oleh alAlbbani dalam Shahih Sunan Abu Daud, hadis no: 3251.

21. Sahih: Dikeluarkan oleh Muslim dalam Shahihnya, hadis no: 1647. 
bahaya kepadanya. Atas dasar inilah, sumpah atas nama selain Allh atau atas nama selain sifat Allah dikatakan sebagai perbuatan syirik (kerana menyakini manfaat dan mudarat datang dari apa yang dijadikan sandaran sumpah dan bukan datang dari Allah).

Selain larangan bersumpah dengan selain Allah, seseorang itu juga diperingatkan agar jangan berdusta dalam sumpah, sekalipun terhadap perkara yang amat kecil. Rasulullah Shallallahu 'Alaihi Wasallam bersabda:

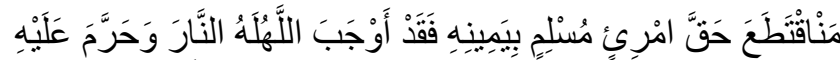

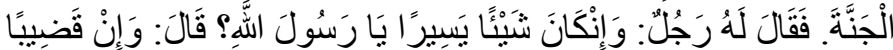

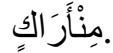

"Sesiapa yang mengambil hak seorang muslim dengan sumpahnya (yang dusta), maka sesungguhnya Allah mewajibkan baginya neraka dan mengharamkan ke atasnya syurga." Lalu seorang (yang hadir bersama) bertanya kepada baginda: "Sekalipun terhadap sesuatu yang remeh ya Rasulullah?" Rasulullah menjawab: "(Ya), sekalipun sebatang kayu arak (yang digunakan untuk bersiwak). "22

Sumpah selanjutnya difahami bahwa ada hal pokok yang perlu tegakkan, yaitu persoalan sumpah harus dilakukan didasarkan atas nama Allah atau sifat dari dari Allah SWT., dan sumpah harus diyakini mempunyai dampak bagi yang bersangkutan akan dampak atau resiko yang akan menimpa terhadap dirinya jika mengandung dusta dan atau tipu muslihat.

a. Bersumpah dengan al-Qur'an

${ }^{22}$ Sahih: Dikeluarkan oleh Muslim dalam Shahihnya, hadis no: 137 
Menurut Kamal bin al-Sayyid Salim hafizhahullah, bersumpah dengan al-Qur'an ialah perkataan Allah (kalamullah) dan ia bukan ciptaan (Allah). Perkataan Allah yang suci itu merupakan satu sifat dari sifat-sifat-Nya. Menurut Jumhur, kecuali Abu Hanifah, berpendapat boleh bersumpah dengan al-Qur'an dan sumpah itu sah. Selanjutnya tokoh Mazhab Hanafi yang mutakhir seperti Ibn al-Hamam dan al-Aini menguatkan pendapat jumhur membolehkan sumpah dengan al-Qur'an. ${ }^{23}$ Siapa yang bersumpah dengan mushaf al-Qur'an sementara yang dia maksudkan ialah perkataan Allah yang tertulis dalam mushaf itu, maka ia dibolehkan. Namun jika yang dia maksudkan ialah lembaran kertas yang tertulis (atasnya ayat al-Qur'an), maka ia tidak dibolehkan. Dan Allah sahaja yang lebih mengetahui. $^{24}$

Persoalan sumpah dengan al Qur'an lebih ditekankan kepada pemahaman yang bersumpah tentang membedakan antara Kalamullah dan tulisan di atas al-Qur'an, maka adalah sumpah dilakukan didasarkan pada al Qur'an sebagai kalamullah adalah sah.

\section{Melanggar Sumpah}

Orang yang bersumpah lalu melanggar sumpah, maka dikenakan sanksi kafarat sumpah berdasarkan firman dalam surat al Maidah 89, Kafarat sumpah yang dilanggar ialah:

1. Memberi makan sepuluh orang miskin dari jenis makanan yang sederhana yang kamu (biasa) berikan kepada keluarga kamu,

\footnotetext{
${ }^{23}$ Wahbah al-Zuhaili,c al-Fiqh al-Islam wa Adillatuhu

${ }^{24}$ Shahih Fiqh al-Sunnah, jld. 2
} 
2. Atau memberi pakaian untuk mereka,

3. Atau memerdekakan seorang hamba.

4. Kemudian siapa yang tidak dapat (menunaikan tiga pilihan kafarat di atas), maka hendaklah dia berpuasa tiga hari.

Melafadzkan sumpah beberapa kali untuk satu perkara yang sama lalu dia melanggarnya, maka kafaratnya hanya sekali dan melafazkan satu sumpah untuk beberapa perkara dengan satu lafaz, maka satu kafarat bagi setiap perkara yang dilanggarnya. ${ }^{25}$

Pelanggaran sumpah yang tidak diwajibkan kafarat, yaitu:

1. Sumpah dusta(al-Yamin al-Ghamus).

2. Percakapan tidak dimaksudkan sebagai sumpah (alYamin al-Laghw), tidak diniatkan oleh hati sebagai sumpah."

3. Orang yang melanggar sumpahnya kerana terlupa, keliru atau dipaksa. Ini berdasarkan keumuman hadis Rasulullah shallallahu 'alaihi wasallam:

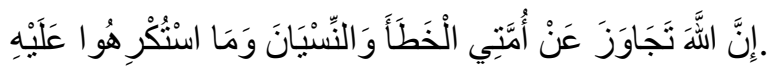

Sesungguhnya Allah memaafkan dari umatku kesilapan, kekeliruan dan apa yang dipaksa ke atasnya. $^{26}$

4. Orang yang telah bersumpah untuk sesuatu yang akan datang, lalu kemudian dia mendapati sesuatu yang lebih baik dari apa yang dia sumpahkan, maka tidaklah bersalah untuk dia melanggar sumpahnya

${ }^{25}$ Shahih Fiqh al-Sunnah, jld. 2

${ }^{26}$ Sahih: Dikeluarkan oleh Ibn Majah dan dinilai sahih oleh al-Albani dalam Shahih Sunan Ibn Majah, hadis no: 1675 
yang awal, asalkan dia membayar kafarat. Dalilnya ialah hadis berikut:

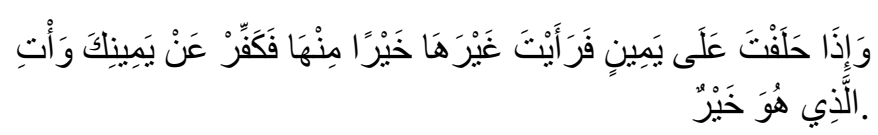

Apabila kamu bersumpah dengan sesuatu sumpah, lalu kamu melihat sesuatu lain yang lebih baik dari apa yang telah kamu sumpah, maka bayarlah kafarat dari sumpah kamu (yang awal itu) dan ambillah yang lebih baik itu. ${ }^{27}$

5. Bersumpah dengan selain Allah

Diketahui terdapat sebahagian pihak yang membolehkan sumpah dengan selain Allah. Mereka berhujah dengan beberapa sumpah Allah Subhanahu wa Ta'ala di dalam al-Qur'an, di mana Allah bersumpah dengan menyandar kepada ciptaanciptaan-Nya. Antara ayat al-Qur'an yang dimaksudkan:

Demi langit dan (bintang) al-Thariq! $!^{28}$

$$
\text { وَالسَّمَاءِ وَالطَّارِقِ. }
$$

$$
\text { 2) وَالْفَجْرِ (1) وَلَيَالِ عَشْرٍ }
$$

Demi waktu fajar dan malam yang sepuluh! $!^{29}$

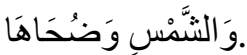

Demi matahari dan cahayanya di pagi hari! ${ }^{30}$

Selain itu pihak yang membolehkan sumpah dengan selain Allah menggunakan hadis berikut sebagai dalil:

${ }^{27}$ Sahih: Dikeluarkan oleh al-Bukhari dalam Shahihnya, hadis no: 6622.

\footnotetext{
${ }^{28}$ al-Thariq 86:01

${ }^{29}$ al-Fajr 89:01-02

${ }^{30}$ al-Syams 91:01
}

Fikri, Vol. 3, No. 1, Juni 2018 


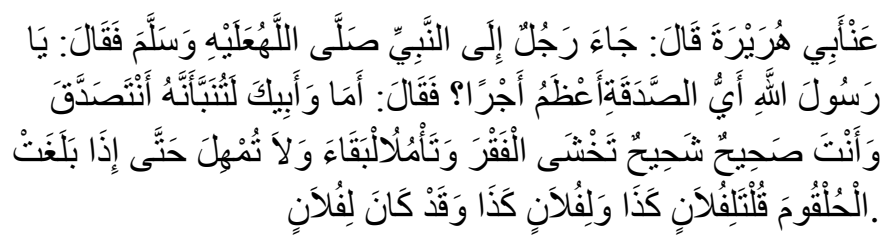

Daripada Abu Hurairah (radhiallahu 'anh) dia berkata, seorang lelaki datang kepada Nabi shallallahu 'alaihi wasallam dan berkata: "Wahai Rasulullah! Apakah sedekah yang paling tinggi anjarannya?"

Rasulullah menjawab: "Demi ayah kamu! Tentu aku akan menjelaskannya. Iaitu sedekah ketika kamu sihat tetapi kedekut kerana bimbang kefakiran dan berharap agar harta itu kekal bersamamu. Janganlah menunda sedekah sehingga ke saat nyawa kamu hampir ditarik, lalu pada saat itu kamu berkata: "Untuk si-fulan harta ini, untuk si-fulan harta itu" padahal pada saat itu harta tersebut memang sudah menjadi hak orang-orang itu.",31

\section{Keluarga/Anak Angkat}

Kedudukan pertalian anak berdasarkan pertalian darah atau sering disebut kedudukan anak kandung. MenurutUU No. 1 Tahun 1974 tentang kedudukan anak, hak dan kewajibannya terhadap oraang tua terdapat pada pasal 42-43 bahwa anak yang sah adalah anak yang dilahirkan dalam atau akibat perkawinan yang sah. Anak yang dilahirkan diluar perkawinan hanya mempunyai hubungan perdata dengan ibunya dan keluarga ibunya. ${ }^{32}$ Sedangkan menurut hukum adat yang berlaku, anak kandung yang sah adalah anak yang dilahirkan dari perkawinan ayah dan ibunya yang sah, walaupun mungkin terjadinya perkawinan itu setelah ibunya hamil lebih dulu sebelum

\footnotetext{
${ }^{31}$ Sahih: Dikeluarkan oleh Muslim dalam Shahihnya, hadis no: 1032-2

${ }^{32}$ Hilman Hadikusuma, Pengantar Ilmu Hukum Adat Indonesia, (Bandung : Mandar Maju, 2014), hlm. 194
} 
perkawinan, sehingga di sebut kappang tubas oleh masyarakat Lampung. ${ }^{33}$

Selain itu, dikenal juga istilah pemungutan anak untuk memberikan kedudukan hukum kepada anak yang dipungut agar lebih baik dan menguntungkan dari semula, contohnya mengangkat anak laki-laki dari selir (Lampung, Bali) dan mengangkat anak tiri menjadi anak sendiri. Perlu ditegaskan, bahwa anak yang diangkat itu umumnya belum kawin dan mayoritas belum tumbuh dewasa.

Pengangkatan Anak (Adopsi) dari segi bahasa (etimologi) yaitu asal usul kata, Adopsi berasal dari bahasa Belanda "Adoptie" $"$ atau Adoption (Bahasa Inggris) yang berarti pengangkatan. Sehingga sering dikatakan "Adoption of a child" yang artinya pengangkatan atau pemungutan anak. ${ }^{35}$

Pengertian adopsi menurut istilah (terminologi), antara lain, menurut Mahmud Syaltut mendefinisikan anak angkat ada dua definisi, adopsi adalah seseorang yang mengangkat anak yang sudah diketahuinya bahwa anak tersebut anak orang lain lalu diperlakukannya seperti anaknya sendiri baik dalam kasih sayang, pendidikan ataupun dalam perbelanjaan. Hanya saja orang tersebut tidak memasukkan nasab anak itu ke dalam nasabnya dan tidak dianggap sebagai keturunannya. ${ }^{36}$ dan Adopsi adalah adanya seseorang yang tidak memiliki anak kemudian menjadikan seorang anak sebagai anak angkat, padahal ia mengetahui bahwa anak itu bukan anak kandungnya, lalu ia menjadikannya sebagai anak sah. ${ }^{37}$ Pengangkatan anak

${ }^{33}$ Ibid, hlm.195

${ }^{34}$ R.Soeroso, Perbandingan Hukum Perdata, (Jakarta: Sinar Grafika, 2005), hlm. 174

${ }^{35}$ Mahjuddin, Masailul Fiqhiyah (Berbagai Kasus yang Dihadapi "Hukum Islam” Masa Kini), (Jakarta : Kalam Mulia, 2003), hlm. 90

${ }^{36}$ Mahmud Syaltut, Al-Fatawa, Alih Bahasa: Bustami A. Gani, Zaini Dahlan, (Djakarta: Bulan Bintang, 1973), hlm.79

${ }^{37}$ Mahjuddin, Masailul Fiqhiyah, hlm.92 
dalam Islam dikenal dan berkembang sebelum kerasulan Nabi Muhammad SAW. Tradisi pengangkatan anak sebenarnya jauh sebelum Islam datang telah dikenal, seperti pada bangsa Yunani, Romawi, India, dan berbagai bangsa pada zaman kuno. Di kalangan bangsa arab sebelum Islam istilah ini dikenal dengan At-Tabanni dan ditradisikan. ${ }^{38}$

Yusuf Qaradhawi menjelaskan adopsi pada era Arab jahiliyah, bahwa pengangkatan anak adalah suatu pemalsuan terhadap realita. Pandangan ini digambarkan bahwa pemalsuan dimana menjadikan seseorang terasing dari lingkungan keluarga aslinya. Anak angkat dapat bergaul bebas dengan perempuan keluarga baru itu dalih sebagai mahram, padahal hakikatnya adalah orang asing. Istri dan ayah begitu juga anak-anaknya, saudara-saudaranya, bibinya bukanlah nasab sehingga bukan mahram. Anak angkat ini dapat menerima waris dan menghalangi keluarga dekat asli yang mestinya berhak menerima. $^{39}$

Anak angkat dalam pengertian hukum adat dapat kita ambil dari berbagai pendapat para Sarjana hukum adat, antara lain, Imam Sudiyat dalam bukunya Hukum Adat Sketsa Asas, tertulis bahwa pengangkatan anak yang terdapat di seluruh Nusantara, ialah perbuatan memungut/mengangkat anak dari luar ke dalam kerabat, sehingga terjalin suatu ikatan sosial yang sama dengan ikatan kewangsaan biologis. ${ }^{40}$ Menurut pendapat Imam Sudiyat, perbuatan pengangkatan anak dalam hukum anak terjadi apabila terciptanya ikatan sosial antara anak angkat dan keluarga angkatnya. Menurut pandangan Hilman Hadi Kusuma, ia mengartikan anak angkat sebagai anak orang lain yang

\footnotetext{
${ }^{38}$ Ibid, hlm.27

${ }^{39}$ Yusuf Qaradhawi, Halal dan Haram, Alih Bahasa : Tim Penerbit Jaba' (Bandung: Jabal, 2009), hlm. 231

${ }^{40}$ Imam Sudiyat, Hukum Adat Sketsa Asas, cet.ke-4 (Yogyakarta: Liberty, 2000), hlm.102
} 
dianggap anak sendiri sebagai penerus keturunan (Lampung : Tegak Tegi) oleh orang tua angkat dengan resmi menurut hukum adat setempat, dikarenakan tujuan untuk kelangsungan keturunan atau pemeliharaan atas harta kekayaan rumah tangga. Pendapat Hilman Hadi Kusuma mengartikan anak angkat yang sah adalah anak orang lain yang telah diakui oleh keluarga angkat dan hukum adat setempat. ${ }^{41}$

Selain itu, Disebut anak angkat adat karena perkawinan, terjadi dikarenakan perkawinan campuran antara suku (adat) yang berbeda. di Lampung, jika suami orang luar, ia dapat diangkat oleh kerabat lelaki pihak ibu (kelama) dan jika istri yang orang luar maka ia dapat diangkat oleh saudara wanita dari bapak (benulung) atau yang bersaudara ibu (kenubi). Anak angkat karena perkawinan ini dilakukan hanya memenuhi syarat perkawinan adat, pengangkatan tersebut tidak menyebabkan si anak angkat menjadi ahli waris dari ayah angkatnya, melainkan hanya mendapatkan kedudukan kewargaan adat dalam kesatuan kekerabatan yang bersangkutan.

Pengangkatan saudara (Lampung: adat mewari/akken anak) tertentu sebagai tanda penghargaan, misalnya mengangkat seorang pejabat pemerintah menjadi saudara angkat. Termasuk pula dalam golongan anak angkat sebagai kehormatan ialah pengangkatan anak karena baik budi, sebagaimana dikatakan orang Minangkabau "kemenakan betali emas" atau juga pengangkatan anak karena perdamaian, sebagai penyelesai perselisihan (akibat perseteruan yang panjang, pembunuhan dan sebagainya). pengangkatan anak karena kehormatan ini juga tidak berakibat menjadi waris dari ayah angkat si anak, kecuali diadakan tambahan perikatan ketika upacara adat di hadapan para pemuka adat dilaksanakan. ${ }^{42}$

\footnotetext{
${ }^{41}$ Hilman Hadikusuma, Pengantar Ilmu, hlm. 201

${ }^{42}$ Ibid, hlm. 202
} 
Umumnya di Indonesia, motivasi pengangkatan anak menurut hukum adat ada 14 macam, antara lain : ${ }^{43}$

1. Karena tidak mempunyai anak.

2. Karena belas kasihan terhadap anak-anak tersebut, disebabkan orang tua si anak tidak mampu memberikan nafkah kepadanya.

3. Karena belas kasihan di mana anak tersebut tidak mempunyai orang tua.

4. Karena hanya mempunyai anak laki-laki, maka diangkatlah anak perempuan atau sebaliknya.

5. Sebagai pemancing bagi yang tidak punya anak,

6. Untuk menambah jumlah keluarga.

7. Dengan maksud agar anak yang diangkat mendapat pendidikan yang baik.

8. Karena faktor kekayaan, diharapkan dengan adanya ankat anak kemudian membuat lebih baik bagi dari salah satu, anak atau orang tua angkat dapat meningkatkan taraf ekonominya.

9. Untuk menyambung keturunan dan mendapatkan pewaris bagi yang tidak mempunyai anak kandung.

10. Adanya hubungan keluarga, mengandung misi kemanusiaan.

11. Diharapkan anak dapat menolong di hari tua dan menyambung keturunan bagi yang tidak mempunyai anak.

12. Ada perasaan kasihan atas nasib si anak yang tidak terurus, misal karenaorang tuanyayang sudah meninggal dunia.

13. Untuk mempererat hubungan keluarga.

14. Karena anak kandung sakit-sakitan atau selalu meninggal dunia, maka untuk menyelamatkan si anak, diberikannya anak tersebut kepada keluarga atau orang lain yang belum

\footnotetext{
${ }^{43}$ Maxbhirawaar, "pengangkatan adopsi anak dalam hukum adat indonesia" dalam maxbhirawaar.wordpress.comsistem.co.id, diunduh pada 12 Mei 2017
} 
atau tidak mempunyai anak, dengan harapan anak yang bersangkutan akan selalu sehat dan panjang usia.

Berkenaan dengan pengangkatan anak, Dalam surat AlAhzab ayat 4-5 dijelaskan: "Allah sekali-kali tidak menjadikan bagi seseorang dua buah hati dalam rongganya; dan dia tidak menjadikan istri-istrimu yang kamu zhihar itu sebagai ibumu, dan dia tidak menjadikan anak-anak angkatmu sebagai anak kandungmu (sendiri). yang demikian itu hanyalah perkataanmu dimulutmu saja. dan Allah mengatakan yang Sebenarnya dan dia menunjukkan jalan (yang benar). Panggilah mereka (anak-anak angkat itu) dengan (memakai) nama bapak-bapak mereka; Itulah yang lebih adil pada sisi Allah, dan jika kamu tidak mengetahui bapak-bapak mereka, Maka (panggilah mereka sebagai) saudara-saudaramu seagama dan maula-maulamu. dan tidak ada dosa atasmu terhadap apa yang kamu khilaf padanya, tetapi (yang ada dosanya) apa yang disengaja oleh hatimu. dan adalah Allah Maha Pengampun lagi Maha Penyayang"(Q.S.A1Ahzab:4-5. ${ }^{44}$ Anak angkat itu hanya sekedar anak pemeliharaan atau anak asuh yang tidak bisa disamakan dengan status anak kandung. ${ }^{45}$

Imam Al-Qurtubi menyatakan bahwa sebelum kenabian, Rasulullah SAW. Sendiri pernah mengangkat Zaid bin Haritsah menjadi anak angkatnya, bahkan tidak lagi memanggil Zaid berdasarkan nama ayahnya (Haritsah), tetapi ditukar oleh Muhammad. Dengan nama Zaid bin Muhammad. Pengangkatan Zaid sebagai anaknya ini diumumkan oleh Muhammad. Di depan kaum Quraisy. Muhammad juga menyatakan bahwa dirinya dan Zaid saling mewarisi. Zaid kemudian dikawinkan dengan Zainab binti Jahsy putri Aminah binti Abdul Muththalib,

${ }^{44}$ Departemen Agama RI, AL-Hikmah AL-Qur'an dan Terjemah, (Bandung: Penerbit Diponegoro, 2007), hlm. 415

${ }^{45}$ Qaradhawi Yusuf, Halal dan Haram, Alih Bahasa : Tim Penerbit Jaba' (Bandung: Jabal, 2009), hlm. 230-231

Fikri, Vol. 3, No. 1, Juni 2018 
bibi Muhammad. ${ }^{46}$ Kemudian setelah Muhammad diutus menjadi Rasul, turunlah wahyu menjelaskan masalah Pengangkatan anak dalam Q.S. Al-Ahzab: 4-5

Sebelum Rasulullah diutus menjadi rasul, beliau mengangkat Zaid ibn Haritsah sebagai anak angkatnya. Zaid adalah seorang budak yang ditawan oleh Khalil, seorang penduduk Tihamah, dari tanah Syam. Zaid dibeli oleh Hakim ibn Hizam ibn Khuwailid, lalu diberikan kepada makciknya, Siti Khadizah. Khadijah memberikan Zaid tersebut kepada Nabi, maka Nabi pun memerdekakan dia dan menjadikannya sebagai anak angkat. ${ }^{47}$

Dalam hadits dari 'Aisyah Ra. berkata, 'Sahlah binti Suhail bin 'Amr mendatangi Rasulullah kala itu ia masih menjadi istri Abu Hudzaifah bin 'Utbah lalu bekata, "Sesungguhnya Salim masuk kepada kami dan kami merasa risih, kami telah menganggapnya seperti anak sendiri. Dan Abu Hudzifah telah mengadopsinya sebagai anak sebagaimana Rosululloh mengadopsi Zaid sebagai anak, maka Allah menurunkan: "Panggillah mereka (anak-anak angkat itu) dengan memakai nama bapak-bapak mereka, itu lebih adil di sisi Allah. ${ }^{48}$

Islam membolehkan melakukan pengangkaan anak dengan prinsip tolong menolong. Para Ulama fikih sepakat menyatakan bahwa Hukum Islam melarang praktek pengangkatan anak yang memiliki implikasi yuridis seperti pengangkatan anak yang dikenal oleh hukum Barat/hukum sekuler dan praktek masyarakat Jahilyah: yaitu pengangkatan anak yang menjadikan anak angkat menjadi anak kandung, anak angkat terputus

${ }^{46}$ Andi Syamsu Alam, M. Fauzan, Hukum Pengangkatan Anak Perspektif Islam, (Jakarta: Kencana, 2008), hlm. 22-23

${ }^{47}$ Teungku Muhammad Hasbi Ash-Shiddieqy, Tafsir Al-Qur'an Majid An-Nuur, Jilid 4, (Semarang: Pustaka Rizki Putra, 2000), hlm. 3252

${ }^{48}$ Al-Muhaddits Asy-Syaikh Muqbal bin Hadi, Shohih Ababun Nuzul, Penerjemah Agung Wahyu, (Depok: Meccah, 2006), hlm. 315-316 
hubungan hukum dengan orang tua kandungnya, anak angkat memiliki hak waris sama dengan hak waris anak kandung, orang tua angkat menjadi wali mutlak terhadap anak angkat. Hukum Islam hanya mengakui pengangkatan anak dalam pengertian beralihnya kewajiban untuk memberikan nafkah sehari-hari, mendidik, memelihara, dan lain-lain, dalam konteks beribadah kepada Allah SWT. ${ }^{49}$

Nabi Muhammad SAW bersabda: Dari Abu Dzar r.a Bahwasannya ia mendengar Rasulullah SAW, bersabda: "Tidak seorang pun yang mengakui (membanggakan diri) kepada orang yang bukan bapak yang sebenarnya, sedangkan ia megnetahui benar bahwa orang itu bukan ayahnya, melainkan ia telah kuruf. Dan barangsiapa yang telah melakukan hal itu maka bukan dari golongan kami (kalangan kaum muslimin), dan hendaklah dia menyiapkan sendiri tempatnya dalam api neraka" (HR. Bukhori Muslim). ${ }^{50}$

Chuzaimah T. Yanggo dan Hafiz Anshary mengemukakan bahwa: Islam dengan tegas mengharamkan perbuatan adopsi yang dilakukan atas dasar:

1. Memungut anak adalah suatu kebohongan di hadapan Allah dan dihadapan masyarakat manusia, dan hanya merupakan kata-kata yang diucapkan berulang kali, tetapi tidak mungkin akan menimbulkan kasih sayang yang sesungguhnya sebagaimana yang timbul di kalangan ayah, ibu dan keluarga yang sebenarnya.

2. Memungut anak sering dijadikan sebagai suatu cara untuk menipu dan menyusahkan kaum keluarga. Misalnya, seorang laki-laki memungut anak yang akan menjadi pewaris dari

${ }^{49}$ Andi Syamsu Alam, M. Fauzan, Hukum Pengangkatan Anak Perspektif Islam), hlm.43-44

${ }^{50}$ Abdullah bin Abdurrahman Ali Bassam, Syarah Hadits Pilihan Bukhari Muslim, (Jakarta: Darul Falah, 2002), hlm. 827 lihat juga di Bukhari, Shahih Bukhari, (Jakarta: Al-Maktabah Al-Śamilah, 2006), Juz 4, hlm. 219

Fikri, Vol. 3, No. 1, Juni 2018 
harta kekayaannya. Dengan demikian berarti orang itu tidak memberikan bagian dari hartanya kepada saudara-saudaranya dan ahli waris yang lain, yang mempunyai hak dalam harta pusaka itu menurut ketentuan Allah.

3. Kemudian, pada gilirannya mengakibatkan haramnya apa yang halal atau sebaliknya, karena anak pungut itu lantas menjadi muhrim dari wanita-wanita dari keluarga yang sebenarnya bukan muhrimnya. Anak angkat lalu merasa boleh melihat bagian-bagian tubuh mereka yang sebenarnya tidak boleh dilihatnya. Di pihak lain menyebabkan ia tidak boleh menikah dengan wanita-wanita yang sebenarnya halal dinikahinya. Demikianlah seterusnya, banyak kerancuan dan kerusakan hubungan keluarga karena anak pungut. ${ }^{51}$

Di Indonesia melalui Pendapat Majelis Ulama Indonesia yang dituangkan dalam Surat Nomor U335/MUI/VI/82 tanggal 18 Sya'ban 1402 H/10 Juni 1982 yang ditandatangani oleh Ketua Umum K.H. M. Syukeri Ghazali, sebagai berikut:

1. Adopsi yang tujuan pemeliharaan, pemberian bantuan dan lain-lain yang sifatnya untuk kepentingan anak angkat dimaksud adalah boleh saja menurut hukum Islam.

2. Anak-anak yang beragama Islam hendaknya dijadikan anak angkat (adopsi) oleh ayah/ibu angkat yang beragama Islam pula, agar ke-Islamannya itu ada jaminan tetap terpelihara.

3. Pengangkatan anak angkat (adopsi) tidak akan mengakibatkan hak kekeluargaan yang biasa dicapai dengan nasab keturunan. Oleh karena itu adopsi tidak mengakibatkan hak waris/wali mewali, dan lain-lain. Oleh karena itu ayah/ibu angkat jika akan memberikan apa-apa

${ }^{51}$ Chuzaimah T. Yanggo, Hafiz Anshary AZ, Problematika Hukum Islam Kontemporer. (Jakarta: Pustaka Firdaus, 1994), hlm. 122-123 
kepada anak angkatnya hendaklah dilakukan pada masa masih sama-sama hidup sebagai hibah biasa.

Adopsi yang dilarang adalah:

Pengangkatan anak yang diajarkan secara Islam apabila memenuhi ketentuan-ketentuan sebagai berikut:

a. Tidak memutuskan hubungan darah antara anak yang diangkat dengan orang tua biologis dan keluarga.

b. Anak angkat tidak berkedudukan sebagai pewaris dari orang tua angkat, melainkan tetap sebagai pewaris dari orang tua kandungnya, demikian juga orang tua angkat tidak berkedudukan sebagai pewaris dari anak angkatnya.

c. Anak angkat tidak boleh mempergunakan nama orang tua angkatnya secara langsung kecuali sekadar sebagai tanda pengenal/alamat.

d. Orang tua angkat tidak dapat bertindak sebagai wali dalam perkawinan terhadap anak angkatnya. ${ }^{52}$

\section{E. Proses Akken Waghei di Kebandaran Mergo Sekampung Udik}

Dalam kekerabatan Masyarakat Lampung Kebandaran Mergo Sekampung Udik dibedakan atas tiga, yaitu: Kekerabatan karena pertalian darah, Kekerabatan karena perkawinan, kekerabatan karena adat. ${ }^{53}$ Kelompok kekerabatan karena pertalian darah, meliputi: Kemaman, yaitu saudara laki-laki bapak, Keminan, yaitu saudara perempuan bapak dan ibu, Kelamo, yaitu saudara laki-laki ibu, Kemenakan, yaitu anak dari saudara laki-laki dan perempuan, Miyaney, yaitu saudara lakilaki, Bay, yaitu saudara perempuan, Benulung, yaitu anak saudara perempuan, LebewKelamo, anak laki-laki dari kelamo,

\footnotetext{
${ }^{52}$ Muderis Zaini, Op. Cit, hlm. 54

${ }^{53}$ Wawancara dengan Turunan Taher, Tokoh Adat Gunung Raya, 21 Oktober 2017
} 
Mighul, yaitu anak kandung dari perempuan. Kelompok Kekerabatan yang bertalian dengan perkawinan, meliputi: Sabai, yaitu seluruh keluarga orang tua dari menantu., Mantew, yaitu menantu, Maghew, yaitu kumpulan suami-suami dari mantu.Kelompok Kekerabatan yang bertalian dengan adat, meliputi: angkat keluarga dalam acara adat, Saudara sumpah.

Akken waghei merupakan adat budaya yang sudah ada turun temurun, sejak kapan hal tersebut ada tidak ada yang tahu pasti. Akken waghei dilakukan dengan berbagai tahap: ${ }^{54}$ Ada kesepakatan yang dibangun terlebih dahulu dari para pihak dan dukungan keluarga para pihak, Menetapkan waktu dan tempat pelaksanaan, Menghubungi tokoh adat, tokoh masyarakat, pamong desa untuk ikut meghadiri dan menyaksikan,Pihak penyelenggara prosesi acara akken waghei mempersiapkan alat berupa al Qur'an, makan bersama, Angkat sumpah,Doa tanda syukur bersama,Makan bersama.Adapun Sumpah dilakukan secara agama Islam, berlandaskan kitab suci al-Qur'an 30 (Tiga Puluh) Juz. Bacaan Sumpahnya adalah Diawali dengan pembacaan alfatihah, bacaan ta'awudz: "auzubillahiminasysyaithanirrajim", lalu basmalah: "Bismilahirrahmannirrahim" saya bersumpah: "Wallahi, Billahi, Thallahi, Saya Bersumpah atas nama Allah bahwa saya mengangkat (si A) sebagai Saudara Saya, orang tua dan saudara si A adalah Orang Tua saya dan Saudara saya, dan saya berjanji tidak akan saling merugikan, tidak saling dendam dan menjaga hubungan keluarga dengan sebaik-baiknya, bilamana saya melanggar sumpah ini saya akan di azab (dilaknat) oleh Allah sesuai al Qur'an 30 (Tiga Puluh) Juz". ${ }^{5}$

${ }^{54 .}$ Wawancara dengan Bapak Khairudin gelar Kriyo Bangsawan, tokoh agama, mantan P3N Desa Bojong, hari Minggu, tanggal 28 Oktober 2017, di Desa Bojong, yang pernah berulangkali menjadi pemimpin angkat sumpah.

${ }^{55}$ Ibid. 
Angken waghei dihadiri berbagai pihak sesuai undangan yng dilakukan pihak penyelenggara, yang hadir pamong desa, minimal Ketua Rukun Tetangga (RT), tokoh adat minimal tokoh adat (penyimbang) dari para pihak akkenwaghei, tetangga sekitar minimal tetangga kiri kanan depan rumah dimana acara dilangsungkan, para kerabat pihak yang akkenwaghei. ${ }^{56}$

Waktu pelaksanaan ditentukan pihak penyelenggara, yang sebelumnya telah disepakati para pihak. Waktu akkenwaghei penting ditentukan sebelumnya karena kaitannya dengan persiapan prosesi akken waghei, yang perlu persiapan mengundang para para tokoh dan masyarakat yang akan hadir menyaksikan acara tersebut, perlu juga persiapan untuk makan bersama yang materialnya perlu dicari dan disiapkan seperti hewan yang akan dipotong, seperti ayam, kambing atau lainnya. ${ }^{57}$

Berdasarkan hasil wawancara dengan bapak Samin Gelar Pangeran Bagindo Rajo tokoh adat dari desa Bojong ${ }^{58}$, dijelaskan bahwa yang bersangkutan pernah beberapa kali melakukan akken waghei dengan beberapa orang, yaitu dengan Harun gelar Kriyo Harun, Ali gelar Pangeran Raja Asli dan Usman gelar Minak Yakin (almarhum) serta Abdurrahman gelar Pangeran (almarhum). Kelima orang ini melakukan angkat saudara secara bersamaan karena ada hubungan keluarga yang sudah jauh tetapi memiliki usaha dagang bersama pada tahun 1975. Agar tidak terjadi perselisihan dan saling tipu-menipu antara mereka.

${ }^{56}$ Wawancara dengan bapak Hasan Pn. Rajo Sebuai bin Muslik, sebagai tokoh adat, LIT desa Bojong hari Sabtu tanggal 28 Oktober 2017 di desa Bojong.

${ }^{57}$ Ibid.

${ }^{58}$ Wawancara dengan Bapak Samin Pangeran Bagido Rajo, Tokoh adat lampung Kebandaran Mergo Sekampung Udik, hari Sabtu tanggal 21 Oktober 2017 di desa Bojong Kecamatan sekampung udik Lampung Timur.

Fikri, Vol. 3, No. 1, Juni 2018 
Pada tahun 1986 terjadi akken waghei antara bapak Samin dengan bapak Kholid bin Walid (Suku Jawa dari Banyu Wangi Jawa Timur), angkat saudara ini disebabkan karena bapak Kholid yang mengendarai mobil menabrak putra ragil bapak Samin bernama Kusairi Bagindo. Karena kecelakaan tersebut tidak sampai timbul korban jiwa baik yang ditabrak atau yang menabrak, yang biasanya yang menabrak akan dikeroyok atau ditusuk dengan senjata tajam bisa menimbulkan kematian. Rasa syukur para pihak sepakat angkat saudara, antara keduanya dan menyatakan Kusairi Bagindo adalah anak angkat bapak Kholid bin Walid. Dilaksanakan dirumah bapak Samin di desa Bojong dan masih terpelihara baik sampai hari ini.

Hasil wawancara dengan Yakup $^{59}$, bahwa yang bersangkutan pernah melakukan angkat saudara sumpah (Akken Waghei), pada tahun 1988 di desa Bojong. Latar belakang angkat saudara sumpah dilakukan karena yang bersangkutan pernah membunuh Idris akibat perkalahian pada saat pesta perkawinan tahun 1980. Setelah menjalani hukuman pidana di LP Cipinang, kekhawatiran akan dendam keluarga dari Idris tetap saja menghantui yang bersangkutan, keluarganya dan masyarakat umumnya dari keluarga Idris (almarhum). Menyelesaikan masalah tersebut dan menghapuskan rasa dendam maka masyarakat berinisiatif mendamaikan Yakup dengan salah satu dari keluarga Idris. Dalam hal ini disepakati perdamaian antara Yakup dan Abdul Latif kakak kandung dari almarhum Idris sehingga tidak ada lagi permusuhan atau dendam dan sudah bergaul sebagaimana biasa orang yang tidak memiliki masalah pada umumnya, saling kunjung dan saling tolong menolong.

59. Wawancara dengan Bapak Yakup Tato, hari Sabtu tanggal 21 Oktober 2017 di desa Bojong Kecamatan sekampung udik Lampung Timur. 
Hasil Wawancara dengan Hasanudin bin Rusdi gelar Kriyo Singo Dewangso, ${ }^{60}$ bahwa yang bersangkutan pernah melakukan angkat saudara (akken waghei) dengan sumpah secara Islam dihadapan kitab suci al-Qur'an. Pada tahun 2001 terjadi pemilihan Kepala Desa yang calonnya terdiri dari Hasanudin Pn. Pesirah dan Ali Imron bin Minak Gal, hubungan antara kedua sangat baik selama ini. Pada 8 (Delapan) tahunan priode kepemimpinan kepala desa sebelumnya Hasanudin sebagai Kepala desa dan Ali Imron pn.Pimpinan sebagai Carik (Sekretaris Desa) setelah selesai masa kepemimpinan tersebut dilakukan kembali pencalonan Kepala desa, dan Keduanya maju sebagai kandidat, berbagai upaya pendekatan kepada warga tentunya dilakukan (kampanye). Dalam kampanye pencalonan Kepala desa berbagai upaya saling jegal, saling menjatuhkan tidak bisa terelakkan, seolah tidak pernah ada hubungan baik, yang akhirnya dimenangkan oleh Hasanudin. Untuk mengakhiri perselisihan akibat persaingan perebutan Kepala desa. bahkan menurut Hasanudin persaudaraan ini sangat sakral, karena di atas sumpah Allah di depan Al-Quran 30 (Tiga Puluh) Juz, wajib untuk dilaksanakan dan dihormati bahkan dalam hubungan sosial melebihi hubungan keluarga kandung untuk diperioritaskan.

Angkat saudara sumpah juga terjadi dengan bapak Mugimin HS bersuku jawa Solo Jawa tengah dengan saudara Ismail bin Hasan Pn. Mangku dari desa Batu Badak bersuku Lampung. Bapak Ismail telah berkeluarga tetapi tidak juga diberi karunia anak selama 7 tahun sejak menikah. uatu hari Ismail dan istri datang ke rumah bapak Mugimin HS, bilamanna mereka mendengar bahwa bapak Mugimin HS adalah orang paranormal yang dapat mengentaskan kesulitan mereka tidak

${ }^{60}$ Wawancara dengan Hasanudin bin Kriyo Singo Dewangso, sebagai tokoh masayarakat, anggota DPRD tk.II Lampung Timur, hari jum'at tanggal 21 Oktober 2017 di desa Bojong Kec. Sekampung Udik Lampung Timur.

Fikri, Vol. 3, No. 1, Juni 2018 
punya anak. Singkat cerita, sangat menggembirakan bapak Ismail dimana istrinya hamil. Dengan keyakinan, bila atas bantuan bapak Mugimin HS telah menolong kesulitannya maka anak yang lahir tersebut bernama Agus bin Ismail di angkenkan (dinyatakan) sebagai anak anak angkat bapak Mugimin HS, peristiwa ini terjadi tahun 1990, di desa Batu Batak. ${ }^{61}$

Wawancara dengan Tulin dan Yusup Kuto Alam, Tokoh Adat dan Tokoh Masyarakat dari desa Toba, Akken waghei tidak selalu dengan angkat sumpah. Akken Waghei dilakukan dengan sumpah biasanya dilakukan bilamana terdapat persoalan yang bisa menimbulkan dan atau karena ada pertikaian. Intinya menjaga keharmonisan dalam bermasyarakat.

Adapun cara lain dapat dilakukan dengan akken anak. akken anak ini dilakukan, Pertama: bilamana seorang berumah tangga tidak memiliki anak. Kedua: bilamana seorang berumahtangga tidak memiliki anak laki-laki yang akan meneruskan ketokohan adat sebagai penyimbang karena dalam sistem kekerabatan masyarakat lampung menganut sistem Patrilineal, dimana laki-laki sebagai pemimpin mengendalikan kekerabatan keluarga (keluarga dan anak buah atau buway lalai). Cara ini dilakukan cukup dengan penerangan ke masyarakat umum dengan cara diundang makan bersama dan mengumumkan bahwa si A telah diangkat keluarga oleh si B, demikian ikrar lainnya jika dianggap perlu dan kepada para penyimbang diberikan uang penerangan tanda hal ini direstui. Selain angkat anak terdapat cara lain yaitu dimasukkan di adat kekerabatan tokoh adat tertentu pada acara perkawinan adat. ${ }^{62}$

\footnotetext{
${ }^{61}$ Wawancara dengan bapak Sugeng, hari Minggu tanggal 4 November 2017 di Bojong.

${ }^{62}$ Wawancara dengan Tulin, tokoh adat Desa Toba, Siapapun dapat masuk adat lampung sepanjang seorang tersebut beragama Islam, tidak dibatasi suku lampung saja, boleh suku jawa, sunda, banten dan sebagainya. Caranya saat ada pesta perkawinan besar untuk penobatan ketokohan adat baru, upacara perkawinan besar seperti ini disebut Begawei, selain diacara
} 


\section{F. Akken Waghei dengan Sumpah dalam Mewujudkan Harmonisasi dalam Kebhinnekaan}

Islam mengenal prosesi sumpah, hal ini untuk meyakinkan sesuatu yang diragukan kebenarannya dan atau digunakan untuk meyakinkan orang lain. Dalam Islam hanya dibolehkan bersumpah atas nama Allah, tidak diperkenankan atas nama lainnya, seperti demi langit dan bumi, demi gunung, demi patung dan sebagainya. Adapun dalam sumpah akken waghei tidak bertentangan karena atas nama atau demi Allah.Bersamaan dengan sumpah yang dilakukan terdapat janji-janji. Janji dalam Islam adalah hutang yang harus dibayar dan atau yang harus ditepati. Dalam janji akken waghei adalah tidak terkait dengan hal yang harus dibayar tetapi harus dijaga dan ditepati. Janji merupakan ikrar yang dibuat berlaku sebagai hukum dan mengikat para pihak yang berjanji. Bagi masyarakat adat kebandaran Mergo Sekampung dimaknai sama bahkan dianggap istimewa karena dilakukan atas nama Allah dan di depan AlQur'an 30 (Tiga Puluh) Juz, rasa kekhawatiran yang besar musibah akan datang padanya maka angkat saudara sumpah ini sangat dijaga dan hati-hati, bahkan diposisikan melebihi saudara kandung, walau sebatas hubungan sosial.

Akken Waghei secara adat tidak menimbulkan perbuatan hukum saling mewarisi, tidak menimbulkan hubungan perwalian dalam perkawinan layaknya wali nasab. Islam memboleh adanya hibah atau wasiat dalam hal pembagian harta baik sewaktu hidup atau setelah kematian. Berkaitan dengan

\footnotetext{
begawei tidak bisa. Terkait dengan suku lain ini ditujukan untuk hubungan yang harmoni antara yang bersangkutan dengan masyarakat lampung, bagi masyarakat lampung diuntungkan karena mendapat keluarga baru sebagai anggota kerabatnaya dan mendapatkan uang jujur karena bayar sejumlah uang dan makan bersama. Bagi yang masuk adat lampung diuntungkan dapat menyatu dan mengikuti acara adat dan mendapat dukungan sebagai keluarga, misal pada acara pemilihan kepala desa, Bupati atau Gubernur.sabtu, 11 November 2017 di desa Toba.
}

Fikri, Vol. 3, No. 1, Juni 2018 
perwalian Islam membolehkan perwalian dengan cara wali tunjuk, dimana diungkapkan dalam Majelis pernikahan, bahwa saya bertindak sebagai wali dari orang tua si gadis yang telah mewakilkan pada saya, lalu ikrar nikah dimulai. Dua hal ini dapat difahami bahwa dalam adat akken waghei seseorang dapat menerima hibah/wasiat atau menjadi wali tunjuk dalam pernikahan tidak secara otomatis karena sudah ada akken waghei tetapi timbul karena ada ikrar akad baru yang melandasinya.

Akkenwaghei dengan sumpah mempunyai tujuan baik, untuk mendamaikan para pihak, secara adat Lampung mempunyai akibat hukum yang mengikat, dalam akken waghei dilakukan dengan sumpah. Dalam sumpah terdapat janji-janji. Janji bagi masyarakat dan agama wajib dilaksanakan, janji adalah hutang. Janji yang dilakukan dengan sumpah mempunyai makna sakral karena disandarkan dengan menyebut nama Allah pada kejadian khsusus serta di depan para tokoh dan masyarakat yang hadir. Janji dalam sumpah disertai kometmen para pihak untuk saling mengakui keluarga atau saudara, tidak dibenarkan saling merugikan, saling mengganggu dan wajib tolong menolong layaknya keluarga yang mempunyai hubungan nasab. Jika dikemudian inkar para pihak menyatakan komitmen akan menerima azab atas cidera janji yang dibuat. Perjanjian yang lahir dari akken waghei suatu hal yang kuat untuk menjalin harmonisasi dalam bermasyarakat bagi masyarakat Lampung. Akhirnya akken waghei dijadikan solusi mencegah adanya perselihan diwaktu kemudian sejak adanya sumpah akken waghei, baik dikarenakan adanya perselisihan sebelumnya dan atau karena hubungan kebaikan yang patut dijaga.

Akken waghei berperan penting untuk mewujudkan harmoni, sebagai berikut:

1. Terjaganya hubungan baik yang sudah berjalan, agar tidak saling merugikan atau yang dapat menimbulkan perselisihan. 
2. Sebagai bentuk hormat atas budi baik kepada seseorang sehingga lebih dieratkan dengan angkat keluarga.

3. Sebagaisolusi menjembatani perselisihan bahkan sampai korban nyawa dengan angkat sumpah para pihak menghilangkan dendam diantara mereka.

4. Sebagai solusi dalam melengkapi kekurangan layaknya keluarga yang ideal,misal angkat anak.

\section{G. Kesimpulan}

1. Akken waghei dilakukan dengan tidak menyalahi syari'at Islam, dan dalam proses pelaksanaannya sangat sesuai dengan tuntunan syar'i. disandarkan pada Allah, dan disandarkan pada kalam Allah idak atas nama lainnya. Angkat keluarga dianggap perjanjian suci, takut akan azab Allah dan dilakukan dalam acara khusus.

2. Peran Akken waghei dalam mewujudkan harmoni dalam bermasyarakat di masyarakat Lampung Kebandaran Mergo Sekampung Udik Lampung Timur sebagai berikut:

a. Terjaganya hubungan baik yang sudah berjalan, agar tidak saling merugikan atau yang dapat menimbulkan perselisihan;

b. Sebagai bentuk hormat atas budi baik kepada seseorang sehingga lebih dieratkan dengan angkat keluarga;

c. Sebagai solusi menjembatani perselisihan bahkan sampai korban nyawa dengan angkat sumpah para pihak menghilangkan dendam diantara mereka;

d. Sebagai solusi dalam melengkapi kekurangan layaknya keluarga yang ideal,misal angkat anak. 


\section{Daftar Pustaka}

Abd Allah bin 'Abd al-Rahman al-Bassam - Taudhih al-Ahkam min Bulugh al-Maram (Maktabah al-Asri, Mekah, 2003)

Abdullah bin Abdurrahman Ali Bassam, Syarah Hadits Pilihan Bukhari Muslim, (Jakarta: Darul Falah, 2002),

Abu Malik Kamal bin al-Sayyid Salim - Shahih Fiqh al-Sunnah wa Adillatuh wa Taudhih Mazahib al-Aimmah (Maktabah al-Taufiqiyyah, Kaherah, $\mathrm{tt}$ )

Ahmad Rafi Baihaqi, Membangun Syurga Rumah Tangga, (surabayah:gita mediah press, 2006)

Ahmad, Syarwani, Muhammad Kristiawan, Tobari Tobari, dan Suhono Suhono. "Desain Pembelajaran SMA Plus Negeri 2 Banyuasin III Berbasis Karakter Di Era Masyarakat Ekonomi ASEAN." Iqra': Jurnal Kajian Ilmu Pendidikan 2, no. 2 (2017): 403-432.

Al-Muhaddits Asy-Syaikh Muqbal bin Hadi, Shohih Ababun Nuzul, Penerjemah Agung Wahyu, (Depok: Meccah, 2006)

Andi Syamsu Alam, M. Fauzan, Hukum Pengangkatan Anak Perspektif Islam, (Jakarta: Kencana, 2008)

Bukhari, Shahih Bukhari, (Jakarta: Al-Maktabah Al-Śamilah, 2006)

C. Dewi Wulandari, Hukum Adat Indonesia Suatu Pengantar, (PT. Refika Aditama, Bandung, 2010)

Cahyono, Heri, Suhono Suhono, dan Aisyah Khumairo. "Pendidikan Karakter Bagi Pelaku Pedofilia (Sebuah Strategi Dalam Mengatasi Amoral)." JMKSP (Jurnal Manajemen, Kepemimpinan, dan Supervisi Pendidikan) 3, no. 1 (2017).

Departemen Agama RI, AL-Hikmah AL-Qur'an dan Terjemah, (Bandung: Penerbit Diponegoro, 2007)

Hilman Hadikusuma, Pengantar Ilmu Hukum Adat Indonesia, (Bandung, Mandar Maju, 2003 
Imam Sudiyat, Hukum Adat Sketsa Asas, cet.ke-4 (Yogyakarta: Liberty, 2000)

Mahjuddin, Masailul Fiqhiyah (Berbagai Kasus yang Dihadapi "Hukum Islam” Masa Kini), (Jakarta : Kalam Mulia, 2003)

Mulyana W. Kusumah, Peranan dan Pendayagunaan Hukum Dalam Pembangunan, (Alumni, Bandung, 1982

Pipin yarifin, Pengantar Ilmu Hukum, (Bandung: Pustaka Setia, 1998)

Qaradhawi Yusuf, Halal dan Haram, Alih Bahasa : Tim Penerbit Jaba' (Bandung: Jabal, 2009)

R.Soeroso, Perbandingan Hukum Perdata, ( Jakarta: Sinar Grafika, 2005)

Soekanto dan Soerjono soekanto, Pokok-Pokok Hukum Adat, (Alumni, Bandung1978)

Soerjono Soekanto, Pengantar Ilmu Hukum, (UI Press, Jakarta, 1994)

Syaikh Kamil Muhammad 'uwaidah, Fiqih Wanita, (Jakarta:pustaka al-kautsar, 1998)

Teungku Muhammad Hasbi Ash-Shiddieqy, Tafsir Al-Qur'an Majid An-Nuur, Jilid 4, (Semarang: Pustaka Rizki Putra, 2000)

Yusuf Qaradhawi, Halal dan Haram, Alih Bahasa : Tim Penerbit Jaba' (Bandung: Jabal, 2009) 
96 Sainul dan Fredy Gandhi Media: Relevansiacara Adat Akken

Fikri, Vol. 3, No. 1, Juni 2018 